\title{
Competitor Threats and the Competitive Advantage among Commercial Banks in Kenya
}

\author{
Paul Waithaka, \\ Department of Business Administration \\ Kenyatta University, Kenya
}

Doi:10.19044/esj.2020.v16n25p72～URL:http://dx.doi.org/10.19044/esj.2020.v16n25p72

\begin{abstract}
Globalization and technological advancement have in a big way altered the business landscape, making it difficult for banks to sustain competitive advantage. The need to enhance competitiveness has forced firms to consider competitive intelligence not only as a tool to guard against competitor threats but also as a mechanism for discovering new opportunities and trends. Competitive intelligence contributes to continuous improvement of the quality of products, services and solutions offered by companies to their clients as well as increasing a firm's innovative capability. Competitor threats have been identified as one of the competitive intelligence domains that a firm needs to focus on in order to gain and sustain competitive advantage. This paper sought to examine the effect of competitor threats on the competitive advantage among commercial banks in Kenya. The target population for the study were directors or managers in-charge of planning or strategy in each of the forty banks in the country. Primary data was collected using a semi structured questionnaire. The questionnaire was tested for both validity and reliability and was found to have met the required threshold. A response rate of $77.5 \%$ was achieved in the study and this was adequate for analysis. The study found that competitor threats had significant effect on the ability of banks to sustain competitive advantage. The study therefore concluded that competitors' threats are real and could inhibit a company's strategy from succeeding in the marketplace and therefore should be detected early. The study therefore recommends that banks should increase the resources devoted to monitoring the competitive landscape to enable early identification of competitors' threats. The study further recommends that banks should develop strategies to neutralize, eliminate or ameliorate those threats.
\end{abstract}

Keywords: Competitor threats; Competitive intelligence; Competitive advantage 


\section{Introduction}

Globalization and technological advancement have greatly changed the business terrain and have made it difficult for companies to keep a sustained competitive advantage (Nenzhelele \& Pellisier, 2014). The increased environmental uncertainties have created a need to monitor and understand the environment more accurately for survival and success (Kalinowski, 2012). The need to enhance competitiveness has forced companies to consider competitive intelligence not only as protective tool to guard against perceived threats and changes, but also as a mechanism for discovering new opportunities and trends (Pirttimaki, 2007).

Dubey and Dubey (2011) noted that competitive intelligence is the right toolkit for managing information, external actors and winning on the business battle field. Competitive intelligence may be regarded as the acquisition, analysis and utilization of information about competitors, new and potential competition, clients, suppliers and governments in order to support decision making for enhancing competitiveness of organizations (Anica \& Cucui, 2009). In order to maintain a sustainable competitive advantage in the fierce business environment, it is certainly important to have a versatile and in-depth understanding of the determinants driving change (Nasri, 2012).

The challenge for organization's management today in their quest to improve performance is how to deal with this changing competitive landscape. Performance measurement is considered as the process of quantifying the effectiveness and efficiency of actions (Alaa \& James, 1996). Ma (2000) observed that competitive advantage and firm performance are two constructs with an apparently complex relationship, while Ray, Barney and Muhanna (2004) found a significant relationship between competitive advantage and performance. Though much empirical works have centered on competitive advantage, the generalization of its relationship to competitive intelligence is under researched (Safarnia, Akbari \& Abbasi, 2011).

\section{Domains of Competitive Intelligence}

The topic of intelligence is vast and has its roots in military science. One of the earliest sophisticated references is the art of war by Sun Tsu (Griffith, 1971) written about $500 \mathrm{BC}$ and has been the basis for development in military intelligence. Intelligence has been a significant factor in military success for thousands of years (McCandles, 2003).The genesis of intelligence activities in the context of commerce and business, is however, a more recent development (Fleisher, 2001). Since the end of the Cold War, competitive intelligence once used in the military environment rapidly infiltrated into the business environment (Deng \& Luo, 2010). When the Cold War came to an end in 1990, downsizing occurred in the United States of America armed forces and related intelligence activities, which resulted in many qualified 
intelligence officers seeking to apply their skills in other arenas. One arena where they found a home was in business organizations (CIR, 1999). Hence the widespread use of competitive intelligence in business organizations today.

Petrisor and Strain (2013) noted that competitive intelligence contributes to the continuous improvement of the quality of products, services and solutions offered by companies, while on the other hand, has an important role in increasing the firm's innovation capability. Fahey (2007) identified five competitive intelligence domains or strategic inputs that researchers in competitive intelligence needs to focus on. These are: market place opportunities, competitor threats, competitive risks, key vulnerabilities and core assumptions. This paper delves in the competitors' threats domain.

A competitor threat is a domain of competitive intelligence that explains the ways a rival inhibits a company strategy from succeeding in the market place. When a threat is detected too late, the resources devoted to this strategy would go to waste. If detected early, strategies could be developed to neutralize, eliminate, ameliorate or avoid the strategy. Calof (2008) stated that competitive intelligence acts as a factor to protect organizations against future risks and recognize hidden opportunities. Moneme, Nzwewi and Mgbemena (2017) state that competitor threats could be mitigated through competitive interdependence where competitive pressures push firms to enter into alliances to limit the number of competitors.

\section{Competitive Advantage}

The pursuit of competitive advantage is an idea at the very heart of strategic management literature (Liao \& Hu, 2007). Levy and Weitz (2001) describe sustainable competitive advantage as an edge over competition that could be maintained over a long time. In order for the organizations to create sustainable competitive advantage, they need to develop a value propositioning that meets the needs of customers in a way that rivals cannot match or easily imitate (Kotler \& Keller, 2006). It is essentially a position of superiority on the part of the firm in relation to its competition in any of the multitude of functions/activities performed by the firm. Ma (1999) categorizes generic competitive advantages into three: ownership based; access- based and proficiency-based.

Barney (2007) noted that competitive advantage is developed on the basis of three characteristics. First, competitive advantage must be able to generate customer value which may be described in terms of speedy delivery, lower price, convenience or other characteristics. Second, the customer must perceive the increased value of the product or service and third, for competitive advantage to be effective it should be difficult for rivals to imitate. While Agbour (2008) asserts that creativity of an organization depends on how 
the leader inspires every employee to bring out their best competencies which they use to transform the organization toward a competitive advantage over its rivals.

Porter (1980) asserts that a firm can achieve competitive advantage through ownership or possession of certain valuable assets, factors or attributes such as strong market position. Barney (1991) noted that it could be developed from a firm being endowed with unique resources, while Hall (1992) says it could come from the firm's reputation. Lieberman and Montgomery (1998) stated that it could be achieved in the form of superior factor market or supply distribution channels. Moreover, a firm could enjoy competitive advantage through its superior knowledge, competencies or capability in conducting and managing its business processes (Teece, Pisano \& Shuen, 1997). Safarnia et al., (2011) state that competitive advantage is born when a firm discovers a new and more efficient way to enter an industry and put that invention in concrete form, than its rivals. This could allow the firm to produce quality products at lower costs and deliver the right product/service in the right place, at the right price and time through the most convenient channel.

\section{Commercial Banks in Kenya}

The banking industry in Kenya is governed by the Companies Act (Cap 486), the Banking Act, the Central Bank of Kenya Act and the various prudential guidelines issued by the Central Bank of Kenya (CBK, 2017). The Industry comprises of 43 commercial banks, 2 mortgage finance companies and 123 foreign exchange bureaus (CBK, 2018). The CBK places commercial banks in Kenya in four broad categories based on ownership; foreign owned locally incorporated, institutions with government participation, foreign owned but locally incorporated institutions (partly owned by locals) and the locally owned institutions (CBK, 2018). Three of the commercial banks have however been placed under receivership by the regulator after experiencing some financial challenges. The study will therefore consider the forty banks that are operating with the direct control of Central Bank of Kenya.

An appropriate banking environment is considered a key pillar as well as an enabler of economic growth (Koivu, 2002). Banks are essential for each country's economy, since no growth can be achieved unless savings are efficiently channeled into investments. Banking industry is competitive and thus requires a lot of creativity and innovation in terms of new product development. As competition among the commercial banks continues to rise, the management of each bank must come up with novel ways of beating the competition, hence the adoption of competitive intelligence. For organizations in the banking industry to become competitive they need to have access to high quality, future oriented information that is necessary for good long term 
decisions (Hughes \& White, 2005). Vargo and Lusch (2008) state that services enable a firm to co-create value based on competencies of company for the customer which leads to resources that are unique and hard to imitate (Wernerfelt, 1984).

\section{Statement of the Problem}

Gwahula (2013) stated that commercial banks play an important role in the socioeconomic development in both developed and developing countries by ensuring prudent allocation as well as efficient utilization of resources. They are continuously helping to channel funds from depositors to investors as well as providing access to a nation's payment system (Ongore \& Kusa, 2013). However, rapid change, hyper competition, changing demographics and customer needs require banks to build adaptability competency for survival and fostering organizational performance (CBK, 2018).

Serieux (2008) noted that the financial systems in Africa and in Kenya specifically were shallow and fragile and hence, unable to effectively contribute to economic development. The shallowness and fragility, the author further observed, was reflected in low lending levels, high interest spread, high levels of non-performing loans and failing of several banks. Upadhyaya (2011) argues that this has led to poor performance of the commercial banks. While Oloo (2013) noted that several commercial banks were declaring losses in their financial reports. This was further affirmed by Onuonga (2014) who stated that the performance of commercial banks in Kenya was not impressive and profitability was on average erratic. This has necessitated the banking institutions to adopt competitive intelligence strategies in order to remain competitive and maintain their industry positions.

Wright (2010) noted that competitive intelligence strategies provide a firm with an objective review of the market place, reduces decision making time, minimizes risks and avoid surprises. It also helps in identification of opportunities before competition does; identification of early warning signals of competitor's moves and reduction of uncertainty. Waithaka (2016) found that competitive intelligence practices impacted the performance of firms listed on the Nairobi securities exchange which include banks. Ngugi, Gakure and Mugo (2012) in an empirical study found the existence of a high correlation between competitive intelligence practices and profitability of firms in the banking industry in Kenya. This study seeks to determine the effect of competitor's threats on sustainable competitive advantage among commercial banks in Kenya. 


\section{Objective of the Study}

To establish the effect of competitor threats on competitive advantage among commercial banks in Kenya

\section{Research Hypothesis}

$\mathrm{H}_{01}$ : Competitor threats have no effect on competitive advantage among commercial banks in Kenya

\section{Significance of the Study}

This study is significance to the management of the banking institutions as it will enable them gain insights on how to apply competitive intelligence strategies to ensure sustained competitive advantage for their organizations. Central bank as the regulator of all the organizations in the banking industry will also gain an understanding on the policies they should formulate to allow the banks to gain competitive advantage. The study has made a contribution to empirical knowledge in this discipline which future researchers can use as a basis for their studies.

\section{Literature Review \\ Porter's Five forces Model}

Porter's (1980) work on the analysis of competitive forces affecting firms, which focused on tracking specific contestant behavior and connecting competitor analysis to competitive strategy, created the background for the development of competitive intelligence as a business discipline (Peyrot, Childs, Van Doren, \& Allen, 2002). Porter took a view of scanning the external environment to gather intelligence on rivals. He (Porter) then developed the Five Forces Model to elucidate the forces that shape competition in an industry. This well-defined analytical structure helps strategic managers to link remote factors and their effects on a firm's operating environment. Porter (1985) identified customers, suppliers, potential entrants, current competitors and substitute products as competitors that may be more or less prominent or active, depending on the industry.

This five forces framework (Porter, 1980) allows a firm to assess both the attractiveness (potential profitability) of its industry and its competitive position within that industry through an evaluation of the strength of the threat of new entrants to the industry; the threat of substitute products; the power of buyers or customers; the power of suppliers (to firms in the industry); and the degree and nature of rivalry among businesses in the industry. According to Porter, the potential for a firm to be profitable is negatively associated with increased competition, lower barriers to entry, a large number of substitutes, and increased bargaining power of customers and suppliers. On the basis of analysis of these forces, Porter argues that an organization can develop a 
generic competitive strategy of differentiation or cost leadership, capable of delivering superior performance through an appropriate configuration and coordination of its value chain activities (Porter, 1985).

Thompson and Strickland (2003) argued that the collective strength of these forces determines the ultimate profit potential of an industry. Whatever their collective strengths, the corporate strategists' goal should be to find a position in the industry where the firm can best defend itself against these forces or can influence them in its favour. They highlight the vital strengths and weaknesses of the company, animate the situation of the company in its industry, elucidate the areas where strategic adjustment might yield the greatest payoffs, and stress the places where industry trends promise to hold the most significance as either opportunities or threats (Charles \& Gareth, 2010). Understanding these forces also proves to be assistance in considering areas for diversification. The model is relevant to this study, as it helps managers identify the boundaries of an industry and its key players and their uniqueness so as to develop strategies to deal with competition in the particular industry.

This model helps firms to understand competitors, their strengths and weaknesses, and gain a thorough knowledge of the competitor's products. With the right kind of information provided by competitive intelligence domains, firms can avoid unpleasant surprises by anticipating competitor's moves and decreasing response time. Competitive intelligence domains identify and describe threats. Understanding the significance and possibility of each threat is valuable since it allows a firm employ more intense defense for its business.

\section{Competitor Threats and Competitive Advantage}

Competitive advantage occurs when an organization acquires or develops an aspect or combination of aspects that allows it to outperform its competitors. These aspects or characteristics can include right to use natural resources, such as high quality raw materials or cheap power, or access to highly skilled and competent human resources. New technologies such as robotics and information technology can provide competitive advantage, whether as a part of the product itself, as an advantage to the making of the product, or as a competitive aid in the business process (for example, better identification and understanding of customers) (Barney, 2007). The term competitive advantage is the ability gained through aspects and resources to perform at a higher level than others in the same industry or market (Cousins, 2005). Superior performance outcomes and superiority in production resources reflects competitive advantage (Gottschalg \& Zollo, 2007). Competitive advantage is the ability to stay ahead of present or potential 
competition, thus superior performance reached through competitive advantage will ensure market leadership.

Competitive Advantage is developed on the basis of three characteristics. First, competitive advantage must be able to generate customer value. Customer value may be defined by the customer in terms of speedy delivery, lower price, convenience, or other characteristics. Second, the customer must be able to perceive the increased value of the product or service. Whether or not the product is superior to the competition is not as important as whether the customer perceives the product to be superior. Third, for competitive advantage to be effective, it should be difficult for competitors to copy (Burden \& Proctor 2000; Barney 2007). The first step in developing competitive advantage is to identify relevant competitors. Next, business owners must identify their strengths and business resources. These might include location, specialty product merchandise, or better-trained and more knowledgeable employees. If the business is a new business venture, this step should focus on the various resources that the business is able to bring together. While these may seem limited compared to the resources of larger competitors, competitive strategy is more about leveraging what resources are available.

Gaining superior organizational performance requires successful efficient and effective utilization of firm resources and competencies with the plan of creating and sustaining competitive advantage locally and globally. Competitive advantage can be defined as a status that organization achieves when it outperforms its competitors in such marketplace (Kleiman, 2000). Porter (1985) asserted that there are two types or models of competitive advantage which are installed in the economic theory. The first one is the market based model which involves the cost and differentiation and argues that market uncovers inefficient organizations particularly those that do not offer products for which consumers are prepared to pay premium price. And it's driven by factors that are external to the firm such as threats and opportunities. The second one is the resource based model which focuses on the firms resources and is driven by factors internal to the firm. Divergent views exist to describe competitive advantage based on different goals of studies. Tracey, Vonderembse and Lim (1999) have investigated competitive advantage from the aspect of, price, cost, delivery, flexibility and quality. Musran (2013) found a positive correlation between total quality management and competitive advantage that consist of, delivery dependability, cost or price, time to market, and product innovation.

Ade, Akaninbi and Tubosun (2017) investigated the influence of competitors' threats on business competitive advantage a case of Diamond Bank in Nigeria and found a very strong correlation. Early identification of competitors' threat was found to have enabled the bank to improve its 
profitability, expand branch network and perform better than its rivals. The study also found that competitor threats had significant influence of business competitive advantage. The study was a case study of only one bank which makes it hard to generalize, while the current study is on all commercial banks in Kenya.

Nematizadeh et al., (2013) examined the effect of competitive intelligence of insurance firms in Kermanshah Iran in a descriptive study. Data was collected from insurance agents of various firms. The results revealed a significant relationship between competitive intelligence and insurance sales. The agents further asserted that understanding of competitors threats was an integral part of competitive intelligence. Kaunyangi (2014) in a study on the impact of competitor threats on the performance of firms in the telecommunication sector in Kenya found that competitors' threats have a great impact on the performance of those firms. The study applied Porter's five forces model in the study. The current study had a different set of variables and was done in the banking industry

\section{Research Methodology}

This study adopted both descriptive and explanatory research designs. Descriptive studies sought to answer who, what, and how questions whereas explanatory research design is about identifying the boundaries of the environment in which the problems, opportunities and situations of interest reside and to identify the salient factors that may be found there that are relevant to the research (Babbie,2002). Mugenda and Mugenda (2003) stated that descriptive design is the process of collecting data in order to test hypothesis or to answer questions on the current status of the subject under study. Descriptive research design approach is credited due to the fact that it allows analysis on the relationship between variables (Creswell, 1999).

The target population for the study were all the commercial banks in Kenya. There are 43 licensed commercial banks that operate in the country but three have been placed under statutory management by the regulator, which is the Central Bank of Kenya. These three banks were not included in this study as their operations are under the regulators and not the managers per se, therefore the population were 40 of the commercial banks. Hence, the unit of analysis in this study was those commercial banks. A census study of those 40 commercial banks was carried out. The population of 40 respondents meets the threshold size of thirty (30) recommended by Mugenda and Mugenda (2003) as ideal to allow normal approximations. The study targeted the manager or director in-charge of planning /strategy in each firm as the unit for observation. Those are the experts in the subject matter within the firm and are believed to be responsible for activities responsible for monitoring competitors' moves in their firm; therefore they were best positioned to 
provide information for this study. Primary data was collected using a semistructured questionnaire which was tested for validity and reliability and found to meet set threshold.

\section{Findings and Discussions}

In the course of the study, a total of 40 questionnaires were distributed to managers or directors-in-charge of planning /strategy in each of the 40 commercial banks operating in Kenya. Out of these questionnaires, 31 of them were completely filed up and returned by these respondents. This was equivalent to a $77.5 \%$ response rate which was in line with Yin (2017) who recommended that an over $70 \%$ response rate as sufficient for presentation of the findings.

Most of the respondents (71\%) were male while (29\%) were female. Majority (52\%) had bachelor's degrees, as their highest level of academic qualifications. Those with Ph.D as their highest level of education were three per cent (3\%). Most of the respondents (35\%) were strategy managers, 29\% planning managers, $26 \%$ planning directors and $10 \%$ director strategy. Most respondents had worked in those positions for more than five years, only $13 \%$ had worked for less than five years. Majority (52\%) had worked for a 6-10 years, 29\% had worked for 11-15 years and 6\% had worked for more than 15 years.

From the findings above, it can be inferred that respondents of the study were educated and thus had knowledge on how to read and interpret the research questions. It can also be deduced that respondents of the study had worked in their respective organizations for a long period of time and thus were knowledgeable about the organizations operations and perfomance. The other inference drawn from the above findings is that respondents who took part in the study were generally in managerial position which in most cases deals with the formulation of key strategies including competitive intelligence and thus they were knowledgeable and quite informed.

Twenty six percent $(26 \%)$ of the banks had been in operation for a period of 11-15 years and majority, (55\%) are Tier III banks. Most of the banks studied (42\%) had 301-400 employees and spend less than 10 Million shillings annually as competitive intelligence activities budget. Twenty nine (29\%) had over 41 branches and frequently at (58\%) collect and analyse information on competitive intelligence. This shows that majority of the studied banks were stable and had invested in competitive intelligence as way of remaining competitive. 
Table 1: Competitor Threats and Competitive Advantage

\begin{tabular}{|c|c|c|}
\hline & Mean & Std. Dev \\
\hline $\begin{array}{l}\text { Competitive intelligence assists the firm to keep abreast with market } \\
\text { information }\end{array}$ & 2.71 & 0.973 \\
\hline $\begin{array}{l}\text { Competitive intelligence helps the firm to track performance of competitor's } \\
\text { products in the market }\end{array}$ & 4.19 & 0.980 \\
\hline Bench-marking activities helps to track what's going on in the industry & 3.42 & 1.501 \\
\hline $\begin{array}{l}\text { The firm analyses competitors' plans and strategies to predict and anticipate } \\
\text { their actions }\end{array}$ & 4.03 & 1.140 \\
\hline es competitive intelligence to estimate competitor's capabilities. & 3.84 & 1.157 \\
\hline to anticipate changes in the business & 3.90 & 1.012 \\
\hline 11. $\quad{ }^{2}$ & 3. & .820 \\
\hline $\begin{array}{l}\text { Competitive intelligence assists in making accurate prediction of competitors' } \\
\text { moves }\end{array}$ & 3.97 & 0.875 \\
\hline ive intelligence enables the firm improve current market position. & 4.10 & 0.885 \\
\hline & 3.94 & 0.814 \\
\hline $\begin{array}{l}\text { Competitive intelligence aids the firm in accurately evaluating suppliers } \\
\text { capability and reliability }\end{array}$ & 3.39 & 0.615 \\
\hline $\begin{array}{l}\text { Competitive intelligence enables the firm to keep an up-to date profile of } \\
\text { competitors }\end{array}$ & 4.13 & 0.885 \\
\hline
\end{tabular}

The findings in Table1 indicate that competitive intelligence helps the banks to track performance of competitor's products in the market, enables the banks to keep an up-to date profile of competitors and improve current market position. The banks analyses competitors' plans and strategies to predict and anticipate their actions. These statements had values of mean above 4.00, with values of standard deviations lower than 1.00. The high mean shows that the respondents agreed with the statements, and a low standard deviation indicated high clustering around the mean of the distribution. This implied that there was close agreement among the respondents on the ability of competitive intelligence activities to help identify competitors' threats.

Further the findings indicate that competitive intelligence assists in making accurate prediction of competitors' moves, regularly prepares profiles of competitors and helps banks to anticipate changes in the business environment. The banks use competitive intelligence to estimate competitor's capabilities and to track trends in the industry. The value of means on these statements ranged from 3.80 to 4.00 , which signifies that respondents were in agreement on them.

Respondents on the other hand were neutral on whether benchmarking activities help to track what's going on in the industry, competitive intelligence aids the banks in accurately evaluating suppliers' capability or competitive intelligence assists the bank to keep abreast with market information with values of means reported as $3.42,3.39$ and 2.72 respectively. 
The values of standard deviations on most of these statements are lower than 1 showing a high level of convergence in the views as expressed by the respondents of the study.

Table 2: Regression Coefficients

\begin{tabular}{llllll}
\hline & \multicolumn{2}{l}{$\begin{array}{l}\text { Unstandardized } \\
\text { Coefficients }\end{array}$} & \multicolumn{2}{l}{$\begin{array}{l}\text { Standardized } \\
\text { Coefficients }\end{array}$} & \\
\cline { 2 - 5 } & B & Std. Error & Beta & t & Sig. \\
\hline (Constant) & 11.194 & 4.527 & & 2.473 & .021 \\
Competitor threats & .316 & .160 & .293 & 1.975 & .000 \\
\hline
\end{tabular}

The results in Table 2 indicate that competitor threats $(\mathrm{p}=0.000>0.05$, $\beta=.316$ ) was found to have significant effect on competitive advantage of commercial banks. The finding agrees with Nematizadeh et al., (2013) who found a significant relationship between competitor threats and insurance sales. These sales agents further asserted that understanding of competitors threats was an integral part of competitive intelligence. The findings also agrees with Ade et al., (2017) who investigated the influence of competitors' threats on business competitive advantage and found a very strong correlation between the two. The study also found that competitor threats had significant influence of business competitive advantage.

The findings further concur with Kaunyangi (2014) who found that competitor's threats had a great impact on the performance of firms in the telecommunication industry in Kenya. This agrees with Nwokah and Ondukwu (2009) who found that competitive intelligence was positively correlated with marketing effectiveness through revealing competitor threats in corporate organizations in Nigeria. However this contradicts Gaspareniene, Remeikiene and Gaidelys (2013) who point out those companies do not always search for information about competitors' actions but might seek to protect their own information from competitors.

\section{Conclusion}

The study therefore concluded that competitors' threats are real and could inhibit a bank's strategy from succeeding in the marketplace and therefore should be detected early to enable the banks to develop strategies to eliminate them or reduce their impact. Competitive intelligence helps banks to track performance of competitor's products in the market, enables them to keep an up-to date profile of competitors and improve current market position. Most banks analyses competitors' plans and strategies to predict and anticipate their actions. Competitive intelligence assists in making accurate prediction of competitors' moves. 


\section{Recommendations}

Competitor threats have significant effect on competitive advantage among commercial banks. On the basis of this finding, the management of commercial banks should invest more resources for the monitoring and analyzing competitor threats. Bank managers should increase the amount of organizational resources devoted to competitive intelligence activities to help reduce managerial myopia in the process of identifying competitor threats. Managers could also mitigate against competitors threats through competitive interdependence where banks enter into strategic alliances to eliminate the number of competitors. Firms should have an avenue or programs in the organization to deliberately plan on how competitors' threats could be neutralized, through regular and continuous scanning of the external environment and identifying major threats that may serve as an antagonism to the company in the marketplace.

\section{References:}

1. Ade, L. P.K., Akanbi A.M. \& Tubosun A.S. (2017). Influence of marketing intelligence on business competitive advantage. Journal of competitiveness, 9, (1), 51-71.

2. Agbour, E. (2008). Creativity and innovation: The leadership dynamic. Journal of Strategic Leadership, 1(1), 39-45.

3. Alaa, M. \& James, S. (1996). The Changing Basis of Performance Measurement, International Journal of Operations \& Production Management, 16 (8), 63-80.

4. Anica I. P. \& Cucui G. (2009). A Framework for Enhancing Competitive Intelligence Capabilities using Decision Support System based on Web Mining Techniques, International Journal of Computers, Communications and Control, IV (4), 326-334.

5. Barney, J.B. (2001). Is the resource-based view a useful perspective for strategic management research? Yes. Academy of Management Review, 26(1), 41-56.

6. Barney, J. B. (1991). Firm Resources and Sustained Competitive Advantage. Journal of Management, 17, 99-120.

7. Barnett, P. W. \& Burgelman, A. R. (1996). Evolutionary perspectives on strategy, Strategic Management Journal, 17, 5-19.

8. Calof, J.L. (2008). Competitive Intelligence A practitioner, academic and interdisciplinary perspective, European Journal of Marketing, 42 (7/8), 717-730.

9. CBK, (2018). Kenyan Banking Sector Records Improved Performance in 2012. Annual Banking Reports. 
10. Charles, W. L. H. \& Gareth, R. J. (2010). Strategic Management Theory: An Integrated Approach, 9th ed. South- Western Cengage, Mason.

11. CIR (1999). Competitive Intelligence Review, 10 (4), 1-84.

12. Cousins, P. D. (2005). The alignment of appropriate firm and supply strategies for competitive Advantage, International Journal of Operations \& Production Management, 25 (5), 403-428.

13. Deng, Z. \& Luo, L. (2010). An exploratory discussion of new ways for competitive intelligence on the Web 2.0.International Federation for Information Processing, 252(1), 597-604.

14. Dubey, R. \& Dubey, U. (2010). An exploratory study on Competitive Intelligence Practices as an Emerging Aproach to Quality Excellence. Indian Journal of Management Science 1, (1), 71-78.

15. Fahey L. (2007). Connecting Strategy and Competitive Intelligence: Refocusing Intelligence to Produce Critical Strategy Inputs. Strategy Leadership, 35(1), 4-12.

16. Gaspareniene, L., Remeikiene,R. \& Gaidelys V. (2013). The Opportunitiess of the use of Competitive Intelligence in Business: Literature Review. Journal of Small Business Development 1, (2) 916.

17. Gottschalg, O. \& Zollo, M. (2007). Interest alignment and competitive advantage. Academy of Management Review, 32 (2), 418-437.

18. Griffith, S.E. (1971). Sun Tsu: The Art of War. New York: Oxford University Press.

19. Gwahula, R. (2013). Efficiency of commercial banks in East Africa: A Parametric Approach, International Journal of Business Management, 8 (4), 50-64.

20. Hall, R. (1992). The Strategic Analysis of Intangible Resources. Strategic Management Journal, 13 (2), 135-44.

21. Hughes, S. \& White, R. J. (2005). Improving Strategic Planning and Implementation in Universities through Competitive Intelligence Tools: A Means to Gaining Relevance, Journal of Education Outreach and Engagement, 10 (3), 39.

22. Kanyaungi, T.W. (2014). The impact of competition on performance of firms in the telecommunication sector in Kenya, International Journal Scientific Research Publication, 4, (11), 1-7.

23. Kotler, P. \& Kelley, K. (2006). Marketing Management, $12^{\text {th }}$ Edition, New Jersey: Pearson Educational Incorporated.

24. Levy, M. \& Weitz, B. (2001). Retailing Management, $4^{\text {th }}$ Edition, New York: McGraw-Hill Companies Inc. 
25. Liao, S. H. \& Hu, T. C. (2007). Knowledge transfer and competitive advantage on environmental uncertainty: An empirical study of the Taiwan semiconductor industry. Technovation, 27, 402-411.

26. Lieberman, M. B. \& Montgomery, D. B.(1988). First Mover Advantages, Strategic Management Journal, 9, 42-58.

27. Ma, H. (2000). Competitive advantage and firm performance. Competitiveness Review, 10, (2),16-17.

28. Ma, H. (1999). Creation and Preemption for competitive advantage, Management Decision, 37 (3), 259-266.

29. Mc Candles, B. (2003). Controversies in Competitive Intelligence: The Enduring Issues. Praeger Publishers, Westport, CT.

30. Moneme, C. P., Nzewi, H. N. \& Mgbemene I.C. (2017). Competitive intelligence and product development in selected pharmaceutical firms in Anambra state of Nigeria, International Journal of Scientific and Research Publications, 7, (4), 288-299.

31. Musran, M. (2013). The Impact of TQM practices Towards Competitive Advantage and Organizational Performance, Pakistan Journal of Commercial and Social Science, 7 (1), 184-197.

32. Nasri, W. (2012). Conceptual Model of Strategic Benefits of Competitive Intelligence Process. International Journal of Business and Commerce, 1 (6), 25-35.

33. Ngugi, J. K., Gakure, R.W. \& Mugo, H. (2012). Competitive intelligence practices and their effect on profitability of firms in the Kenyan Banking Industry, International Journal of Business and Social Research, 2, (3), 11-18.

34. Oloo, O. (2011). Banking Survey Report, The best banks this decade 2001-2010, Think Business Limited, Kenya, www.bankingsurvey.co.ke

35. Onuanga, S. M. (2014). The analysis of profitability of Kenya's Top Six Commercial Banks: Internal Factor Analysis, International American Journal of Social Science 3 (5), 94-103.

36. Peyrot, M. Childs, N. Van Doren, D. \& Allen, K. (2002). An Empirically Based Model of Competitor Intelligence Use, Journal of Business Research, September; 55(9), 747-758.

37. Pertisor, I. \& Strain, N.A. (2013). Approaches on competitive intelligence. The USV Annals of Economics and Public Administration, 13, 1 (17).

38. Pirttimäki, V. (2007).Comparative Study and Analysis of the Intelligence Activities of Large Finnish Companies, Journal of Competitive Intelligence and Management, 4, (1), 147-170.

39. Porter, M.E. (1985). Competitive Advantage. The Free Press, NY.

40. Porter, M.E. (1980). Competitive Strategy. New York, NY: Free Press. 
41. Ray, G., Barney, J. B. \& Muhanna, W. A. (2004). Capabilities, business processes, and competitive advantage: Choosing the dependent variable in empirical tests of the resource-based view. Strategic Management Journal, 25, 23-37.

42. Safarnia, H. Akbari, Z. \& Abbasi, A. (2011). Review of Competitive Intelligence and competitive advantage in industrial estates companies in Kerman city, International Business and Management, 2 (2), 47-61.

43. Serieux, J. (2008). Financial Liberalization and Domestic Resource Mobilization in Africa: Assessment, International Poverty Centre Working Paper, 45.

44. Thompson, A. A. \& Strickland, A. J. (2003). Strategic Management Concepts and Cases $13^{\text {th }}$ ed. New York, NY, McGraw-Hill, Higher Education.

45. Upadhyaya, R. (2011). Analyzing the Sources and impact of Segmentation in the Banking Sector: A Case study of Kenya. Unpublished $\mathrm{Ph}$. D Thesis presented to the University of London.

46. Vargo, S. L., \& Lusch, R. F. (2008). Service-dominant logic: continuing the evolution. Journal of the Academy of Marketing Science, 36 (1), 1-10.

47. Waithaka, P. (2016). Competitive Intelligence Practices and Performance of Firms listed on the Nairobi securities Exchange, Kenya, European Scientific Journal, 12, (19), 107-126.

48. Wernerfelt, B. (1984). The Resource-Based View of the firm. Strategic Management Journal, 5 (2), 171-180.

49. Wright, S. (2010). Capitalizing on intelligence: converting input to output to insight and competitive advantage. Journal of Strategic Marketing, 18 (7), 517-521. 